\title{
Immobilization and Characterization of Levansucrase Enzyme onto Functionalized Multi-walled Carbon Nanotubes
}

\author{
Ahmed A. Haroun ${ }^{1 *}$, Eman F. Ahmed ${ }^{2}$, M.A. Esawy ${ }^{2}$ \\ ${ }^{1}$ Chemical Industries Research Division, National Research Centre, 12622 Dokki, \\ Giza, Egypt. \\ ${ }^{2}$ Chemistry of Natural \& Microbial Products Dept, National Research Centre, 12622 \\ Dokki, Giza, Egypt.
}

\begin{abstract}
$\mathbf{U}$ SING of enzymes in some industrial applications is still limited due to their instability under severe conditions, and relatively high production charge. Accordingly, this work deals with preparation and characterization of novel biocatalysts based on functionalized multi-walled carbon nanotubes (MWCNTs) with calix[8]arene in presence of N-ethyl-N-(3dimethylaminopropyl) carbodiimide, (EDC) and glutardialdehyde (GA) crosslinkers. Among 5 honey isolates, the most potent levansucrase producer was identified based on 16S rRNA as Bacillus subtilis. Moreover, in case of using $4000 \mathrm{U} / \mathrm{g}$ enzyme concentration, the enzyme gave the highest immobilization yield (81\%) onto uncrosslinked MWCNTs/calix[8]arene. The prepared materials were characterized using: FTIR, TEM and particle size distribution analysis. EDC had significant effect on the particle size $(938 \mathrm{~nm})$ relative to that in case of GA (746-784 $\mathrm{nm}$ ) and un-functionalized MWCNTs (419 nm). Besides, the cytotoxicity of the immobilized enzyme could be minimized up to $100 \mu \mathrm{g} / \mathrm{mL}$ concentration against BHK fibroblast normal cells in comparison with the free enzyme and MWCNTs. In general, all the prepared formulations improved the enzyme stability to great instance in comparison with the free enzyme.
\end{abstract}

Keywords: Multi-walled carbon nanotubes, Calix[8]arene, Levansucrase, Covalent immobilization, Cytotoxicity.

\section{Introduction}

Carbon nano tubes (CNTs) have been used in nanotechnology field to create new functional nanostructures, due to its exceptional mechanical, electrical and chemical properties. Consequently, there is now an increasing interest in understanding and controlling the interactions of them with biological molecules, such as enzymes [1-7].

Enzyme immobilizations on carbon nanotubes (CNTs) for fabrication of biofuel cells and for preparation of biocatalysts are rapidly emerging as new research areas. Various immobilization methods have been developed, and in particular, specific attachment of enzymes on carbon nanotubes has been an important focus of attention. The method of immobilization has an effect on the preservation of the enzyme structure and retention of the native biological function of the enzyme [8].
Nanotechnology-inspired biocatalyst systems have attracted a lot of attention in enzyme immobilization recently. However, common immobilization methods have limited the applicability of these biocatalysts owing to enzyme leaching, 3Dstructure loss, strong diffusion resistance and expensive enzyme purification requirement before immobilization. Site-specific enzyme immobilization method overcomes the foresaid limitations. It is based on the specific interaction between His-tagged enzyme and carbon nanotubes modified with $\mathrm{N}(\alpha), \mathrm{N}(\alpha)$-bis (carboxymethyl)-L-lysinehydrate. This method does not require enzyme purification and the resulting nanoscale biocatalyst can maintain high enzyme activity and stability $[9,10]$.

Functionalization of CNTs with organic, polymeric, and biological molecules can provide biocompatible nanotube composites with specific 
groups on their surface. Also, Haroun et al. [11, 12] reported that novel carbon baste electrode and functionalized MWCNTs-based nanocomposites using $\beta$-cyclodextrin could be prepared for several applications. Furthermore, recently some bioactive materials such as citrus extract or soyasapogenol B were successfully immobilized onto functionalized MWCNTs [13, 14].

Enzyme immobilization is advantageous due to enzyme recovery from product be easier, also enzyme reuse and process scaling up. Moreover, immobilized enzymes sometimes have higher activity, stability, selectivity and resistance to inhibitors [15-17]. Levansucrase (EC2.4.1.10) is a fructosyl transferase forming levan from sucrose that is ab-2, 6-linkedfructosehomopolymer with some b-2,1-linked branched point [18, 19]. The main levansucrase property is synthesis of-(26)-levan by transferring fructosyl group of nonactivated sucrose into fructan chain [20].

Also, it has become a common goal for many workers in the microbiological and medical fields, due to the apparent significance of this group of enzymes in tumor therapy via exchanging the anti tumor activity of leukocytes. There are several factors controlling the enzyme immobilization including enzyme concentration, matrix type, binders and crosslinkers. Nowadays, few studies were mentioned in levansucrase immobilization due to the interference of the levan polymer with the levansucrase enzyme during the immobilization process affording enzyme inactivation [21]. Consequently, in this work levansucrase immobilization onto functionalized MWCNTs with calix[8]arene using simple covalent binding technique has been carried out. In addition the enzyme activity and cytotoxicity of the immobilized enzyme were investigated in comparison with the free enzyme and MWCNTs.

\section{Experimental}

\section{Materials}

- Multi-walled carbon nanotubes (MWCNTs), carbon $>95 \%$, O.D L 6-9 nm $5 \mu \mathrm{m}$, Calix[8] arene $90 \%, \mathrm{~N}, \mathrm{~N}$ bis carboxymethyl-L-lysine hydrate $97 \%$, cobalt (II) chloride 98\%, Nhydroxysuccinimide (NHS) and N-ethyl-N-(3dimethyl aminopropyl) carbodiimide (EDC), crosslinker were obtained from Sigma-Aldrich.

- Normal fibroblast (BHK), and breast carcinoma (MCF-7) cell lines were collected and prepared for SRB cytotoxicity assay by National Cancer Institute, Cairo University.

Egypt. J. Chem. 61, No. 4 (2018)
- HEPES sterile buffer 1M obtained from BioWest.

- All chemicals and other reagents will be used without further purification.

\section{Methods}

Isolation of bacterial strain from honey

Bacterial honey isolates were isolated from Nigerian bee honey collecting nectar from mountain flower. Honey's samples are fresh non treated ripe honey (directly collected in beehives). These strains were subculture in agar medium and the arisen colonies were harvested by glycerol solution $(50 \%)$ and put in series of $2 \mathrm{~mL}$ cryogen vials (Nalgene, USA). Tubes were frozen immediately at $-20{ }^{\circ} \mathrm{C}$ for $24 \mathrm{~h}$ followed by storage as working cell bank at $-80{ }^{\circ} \mathrm{C}$ for further study. This was an important step to ensure that the starter culture of each experiment of the same generation number.

\section{S rRNA Analysis technique}

Preparation of template DNA

A pure cultivated bacterium was used for identification. Colonies were picked up with a sterilized toothpick suspended in $0.5 \mathrm{~mL}$ of sterilizes saline in $1.5 \mathrm{~mL}$ centrifuge tube and centrifuged at $10000 \mathrm{rpm}$ for $10 \mathrm{~min}$ (Sigma 3-16KL model). Supernatant was removed and the pellet was suspended in $0.5 \mathrm{~mL}$ of Insta Gene Matrix (Bio-Rad, USA). Incubated at $56^{\circ} \mathrm{C}$ for $30 \mathrm{~min}$ and then heated at $100^{\circ} \mathrm{C}$ for $10 \mathrm{~min}$. After heating, supernatant can be used for PCR. Template DNA $1 \mu \mathrm{L}$ in $20 \mu \mathrm{L}$ of PCR reaction solution $27 \mathrm{~F} / 1492 \mathrm{R}$ primers was used for bacteria, then 35 amplification cycles at $94{ }^{\circ} \mathrm{C}$ for $45 \mathrm{sec}$, at $55^{\circ} \mathrm{C}$ for $60 \mathrm{sec}$, and at $72^{\circ} \mathrm{C}$ for $60 \mathrm{sec}$ were performed. DNA fragments were amplified about $1400 \mathrm{bp}$ in the case of bacteria. Include a positive control (E.coli genomic DNA) and a negative control in the PCR.

\section{Sequencing}

The purified PCR products of approximately $1400 \mathrm{bp}$ were sequenced by using 2 primers AGA GTT TGA TCM TGG CTC AGTAC GGY TAC CTT GTT ACG ACT T and CCA GCA GCC GCG GTA ATA CGTAC CAG GGT ATC TAA TCC. Sequencing was performed by using big dye terminator cycle sequencing kit (Applied Bio-Systems, USA). Sequencing products were resolved on an Applied Biosystems model 3730XL automated DNA sequencing system, according to Baxevanis A.D. [22].

\section{Purification and oxidation of MWCNTS}

Pristine MWCNT (100 mg) was dispersed in mixed concentrated sulphuric and nitric acids 
$(3: 1, \mathrm{v} / \mathrm{v})$ at ratio of $50 \mathrm{~mL}$ acid mixture [23]. The resulted mixture was then heated at $110^{\circ} \mathrm{C}$ overnight with continuous stirring to produce oxidized carbon nanotubes (MWCNTs- $\mathrm{COOH}$ ). The sample washed with ultrapure water until got neutral filtrate $(\mathrm{pH}$ 7.0). The collected solid was dried under vacuum at $70^{\circ} \mathrm{C}$ for $12 \mathrm{~h}$ and kept for further functionalization and analysis.

\section{Enzyme production}

Levansucrase production medium was prepared and sterilized including the following nutrients (g/L); (80) sucrose, (0.2) $\mathrm{MgSO}_{4}$, (5.5) $\mathrm{K}_{2} \mathrm{HPO}_{4}$ and (2.5) yeast extract. Each strain of the isolated bacteria was used to inoculate $50 \mathrm{~mL}$ of the production medium in $250 \mathrm{ml}$ flasks stirred at $150 \mathrm{rpm}$ and incubated for $48 \mathrm{~h}$ at $30^{\circ} \mathrm{C}$. After incubation period, each flask was centrifuged and the filtrate was applied for evaluation of enzyme and protein concentrations by using Lowry method [24].

\section{Partial purification}

The partial purification was carried out by fractionated the culture filtrate using different concentrations (30-90\%) of acetone. Each fraction was centrifuged at $4^{\circ} \mathrm{C}$ and levansucrase enzyme activity was checked in each precipitate.

Immobilization of levansucrase enzyme onto functionalized MWCNTS

The MWCNTs functionalization was demonstrated using covalent binding process in combination with sonication strategy [25]. MWCNTs-COOH powder and/or calix[8]arene $(10 \mathrm{mg})$ were dispersed in $200 \mathrm{~mL}$ HEPES buffer, then reacted with $100 \mathrm{mMN}$-hydroxy succinimide (NHS) as well as (1\%) glutardialdehyde (GA) or
EDC. $20 \mathrm{mM}$ N,N-bis(carboxymethyl) L-lysine hydrate (ANTA) was dissolved in HEPES buffer with excess cobalt chloride $\left(\mathrm{CoCl}_{2}\right)$ to form ANTA-Co . Excess $\mathrm{Co}^{2+}$ was precipitated by $\mathrm{NaOH}$. The resulting $\mathrm{Co}(\mathrm{OH})_{2}$ was removed by centrifugation at $8000 \mathrm{rpm}$ for $10 \mathrm{~min}$. The supernatant containing ANTA-Co was collected then mixed with above mixture to produce ester complex. The byproducts and excess NHS were removed by washing the complex with $20 \mathrm{mM}$ HEPES. Different concentrations of levansucrase enzyme (3200,4000 and 3600 $\mathrm{U} / \mathrm{g}$ ) was incubated with the ester complex at $4^{\circ} \mathrm{C}$ overnight and the resulting conjugate was collected by centrifugation. Different immobilized enzyme formulations (1,2 and 3) were washed with HEPES buffer, dried and kept for further investigation (Table 1).

\section{Enzymatic activity \\ Levansucrase assay}

According to the method of Yanase et al. [26] with some modification. $0.5 \mathrm{ml}$ of culture filtrate was incubated with $1 \mathrm{ml}$ of $20 \%$ sucrose and $1 \mathrm{ml}$ of $0.1 \mathrm{M}$ acetate buffer at $\mathrm{pH} 5.2$ and incubated at $30^{\circ} \mathrm{C}$ for $15 \mathrm{~min}$. The produced reducing sugar was measured by glucose oxidase kits. One unit of enzyme activity was defined as the amount of enzyme that produces reducing sugars equivalent to $1 \mu \mathrm{mol}$ of glucose per min.

\section{Thermal stability}

The effect of temperature on free and immobilized levansucrase was carried out by preheating the levansucrase at different temperature $\left(30-60^{\circ} \mathrm{C}\right)$ and different time intervals $(30,60,90$, $120 \mathrm{~min}$ ). Then residual activity was determined under the optimized condition.

TABLE 1. Chemical composition of the prepared materials.

\begin{tabular}{cc}
\hline Sample code & Chemical composition \\
\hline B & MWCNTs \\
$(1)$ & MWCNTs/Calix/ GA ${ }^{\text {I }}$ \\
$(2)$ & MWCNTs $/ \mathrm{Calix}^{\text {II }}$ \\
$(3)$ & MWCNTs/Calix/EDC ${ }^{\text {III }}$
\end{tabular}

Levansucrase concentrations: I: 3200 , II: 4000 and III: 3600 U/g.

EDC: $1 \%$ Nethyl-N(3-dimethyl aminopropyl) carbodiimide.

GA: $1 \%$ Glutardialdehyde.

Calix: $10 \mathrm{mg}$ of Calix[8]arene.

MWCNTs: $10 \mathrm{mg}$ of oxidized multi-walled carbon nanotubes. 
Cytotoxicity measurements using SRB assay

Potential cytotoxicity of the prepared nanomaterials was tested using the method of Skehan et al. [27] as follows: Different cell lines [normal fibroblast (BHK) and breast carcinoma (MCF7)] were plated separately in 96-multiwell plate (10 cells/well) for $24 \mathrm{~h}$ before treatment with the prepared formulations to allow attachment of cell to the wall of the plate. Different concentrations of the obtained materials under investigation $(0,10,25,50$ and 100) $\mu \mathrm{g} / \mathrm{mL}$ were prepared for each individual dose. Monolayer cells were incubated with the prepared materials for $48 \mathrm{~h}$ in $5 \%$ carbon dioxide atmosphere at $37^{\circ} \mathrm{C}$. After $48 \mathrm{~h}$ cells were fixed, washed and stained with sulpho-rhodamine-B stain (SRB). Excess stain washed with acetic acid and recovered with Tris-EDTA buffer. Colour intensity was measured in an ELISA reader. The relation between surviving fraction and the prepared formulation concentrations was plotted to get the survival curves of the used cell lines.

\section{Statistical analysis}

The data will be expressed as mean \pm SD. Differences between non-treated and treated cells with the prepared formulations will be analyzed using an unpaired t-test.

\section{$\underline{\text { Result and Discussion }}$}

\section{Levansucrase Production}

Five bacteria were isolated from mountain honey and screening for levansucrase production. They coded H1, H2, H3, H4 and H5. The most potent isolate was $\mathrm{H} 4$. It had the highest levansucrase production $(54.07 \mathrm{U} / \mathrm{ml})$ and specific activity (13 U/mg) as shown in Table 2. This result was higher than that the previous studies which mentioned the activity of Bacillus subtilis NRC levansucrase and lower than that in the case of the two Bacillus subtilis $\mathrm{K}$, M levansucrase activity recorded under the optimized conditions (19.5 and 59.0, 62.0 U/mL, respectively) [28, 29]. The isolate was identified based on $16 \mathrm{~S}$ rRNA gene sequencing as Bacillus subtilis with similarity $100 \%$. The enzyme was partially purified by fractional precipitation with acetone. The most active fractions were obtained at $60 \%$ concentration and recorded the highest specific activity (145.7 U/mg).

\section{Characterization of levansucrase immobilized MWCNTS}

The enzyme was loaded onto three different formulations (1) MWCNTs/calix[8]arene/GA, (2) MWCNTs/ calix[8]arene and (3) MWCNTs/ calix[8]arene/EDC, with different enzyme concentrations 3200, 4000 and $3600 \mathrm{U} / \mathrm{g}$, respectively and crosslinkers (GA and EDC). Formulation 1 recorded the highest immobilization yield (81\%), followed by formulations 2 and 3 (75.0 and $69.5 \%$, respectively). This means that crosslinkers played an important role in levansucrase activation and stabilization. Also, the activity of the unbound enzyme was zero suggested that the enzyme was completely immobilized onto the functionalized MWCNTs. However, the enzyme activity affected according to the formulation condition. On the other hand, calix[8]arene played also an important role in the immobilization efficiency, because it has cavity structure leading to enzyme embedding enhancement. These results were in accordance with that of Veesar et al [30] who reported

TABLE 2. Levansucrase enzyme activity of the different bacterial honey isolates.

\begin{tabular}{lcc}
$\begin{array}{c}\text { Code of } \\
\text { isolated bacteria }\end{array}$ & $\begin{array}{c}\text { Activity } \\
(\mathbf{U} / \mathbf{m L})\end{array}$ & $\begin{array}{c}\text { Specific activity } \\
(\mathbf{U} / \mathbf{m g})\end{array}$ \\
\hline $\mathrm{H} 1 \mathrm{(U/ml)}$ & 36.92 & 10.5 \\
$\mathrm{H} 2$ & 6.259 & 8.2 \\
$\mathrm{H} 3$ & 11.33 & 7.8 \\
$\mathrm{H} 4$ & 54.07 & 13.0 \\
$\mathrm{H} 5$ & 41.18 & 11.7 \\
\hline
\end{tabular}


that the calix[4]arene immobilized $\alpha$-amylase retained $85 \%$ of its original activity and showed significant thermal stability and durability than the free enzyme. Also, B. amyloliquefaciens levansucrase was immobilized onto glyoxyl agarose-iminodiacetic acid/Cu/polyethyleneimine by covalent method to show an activity yield of $54.69 \%$ [31].

Figure 1 shows FTIR spectra of the prepared levansucrase immobilized formulations (1) in comparison with calix[8]arene and (B) MWCNTs. IR spectrum of the crosslinked MWCNTs/ calix[8]arene with GA (sample 1) had small characteristic peaks at 1638 and 1394 $\mathrm{cm}^{-1}$ corresponding to the reacted carbonyl groups. While, calix[8]arene spectrum showed characteristic peaks at 2877,2952 and 3035 $\mathrm{cm}^{-1}$ corresponding to the $\mathrm{CH}, \mathrm{CH} 2$ and $\mathrm{CH} 3$ groups, respectively. All other characteristic peaks corresponding to the different functional groups such as $\mathrm{C}=\mathrm{C}, \mathrm{C}-\mathrm{O}, \mathrm{C}-\mathrm{C}$ aromatic, and $\mathrm{CH}$ aromatic were observed. In other words, all spectra showed that no changing in the characteristic peaks of MWCNTs and calix[8] arene after enzyme immobilization. This indicating ${ }_{2+}$ that enzyme was immobilized via ANTA-Co side reaction not onto MWCNTs backbone structure.

Figure 2 shows TEM images of the prepared levansucrase immobilized formulations (1) MWCNTs/calix[8]arene/GA, (2) MWCNTs/ calix[8]arene and (3) MWCNTs/calix[8]arene/ EDC in comparison with (B) MWCNTs. It was observed that, the size and morphology of the different formulations were recorded with the same resolution $(100 \mathrm{~nm})$. The immobilized enzyme via covalent binding was confirmed by increasing diameters and consequently the thickness of the sidewall of the functionalized MWNT relative to the un-immobilized samples. Similar observations of uniform coating of the Candida rugosa lipase to the MWNT via physically adsorption were also previously reported [30].

Figure 3 and Table 3 show particle size distribution of the prepared levansucrase immobilized formulations (1), (2) and (3) in comparison with (B) MWCNTs using DLS technique. It can be observed that the presence of macrocyclic molecule, calyx[8]arene, increased significantly the particle size of the functionalized MWCNTs (about 746, 784 and 938 $\mathrm{nm}$, respectively) relative to MWCNTs $(419 \mathrm{~nm})$. In other words, EDC crosslinker had great effect on the particle size of the functionalized MWCNTs $(938 \mathrm{~nm})$ in spite of the different immobilized levansucrase enzyme concentrations.

Figure 4a shows in vitro cytotoxic activity of the prepared levansucrase immobilized formulations (1), (2) and (3) in comparison with MWCNTs and free enzyme using BHK normal cell line using SRB assay. It was observed that when the carrier's concentration was increased, the surviving fractions were decreased and consequently the dead cells (\%) were increased. This may be due to the controlled release quantity of enzyme in the culture media. Also the same behavior was found in case of the un-immobilized compound (B) MWCNTs relative to the free enzyme. While, Fig $4 \mathrm{~b}$ shows in vitro cytotoxic activity of MWCNTs in comparison with the free levansucrase enzyme against BHK and MCF7 carcinoma cell lines using SRB assay. The free enzyme exhibited high cytotoxic activity against normal BHK and MCF7 cell lines relative to MWCNTs up to concentration $100 \mu \mathrm{g} / \mathrm{mL}$. It can be concluded that the presence of macrocyclic compound, calix[8]arene, inside the prepared formulations, controlled the enzyme release and consequently retarded the cytotoxic effects of levansucrase enzyme against normal BHK and breast carcinoma MCF7 cell lines.

\section{Thermal stability}

Figure 5 shows thermal stability of the prepared levansucrase immobilized formulations (1), (2) and (3) relative to the free enzyme form. As expected, the free enzyme form lost about $90 \%$ of its activity at $60^{\circ} \mathrm{C}$ after $120 \mathrm{~min}$. While, most of the prepared formulations enhanced the enzyme stability to great instance in comparison with the free form. Immobilized levansucrase formulations could remain about 91,78 and $88 \%$, respectively, of its original activity at $40^{\circ} \mathrm{C}$ after 120 min relative to the free form $(68 \%)$. On the other hand, the relative enzyme activity could remain about 41,26 and $38 \%$, respectively, of its original activity at $60^{\circ} \mathrm{C}$ after $120 \mathrm{~min}$ relative to the free form $(10 \%)$. In other words, immobilized levansucrase enzyme kept most of its activity at $40^{\circ} \mathrm{C}$ after $120 \mathrm{~min}$. It can be concluded that the formulation (1) MWCNTs/ calix/GA was the best one. These findings proved that the presence of calix[8]arene cavity and GA crosslinker during the enzyme immobilization played an important role in the enzyme stability.

Egypt. J. Chem. 61, No. 4 (2018) 


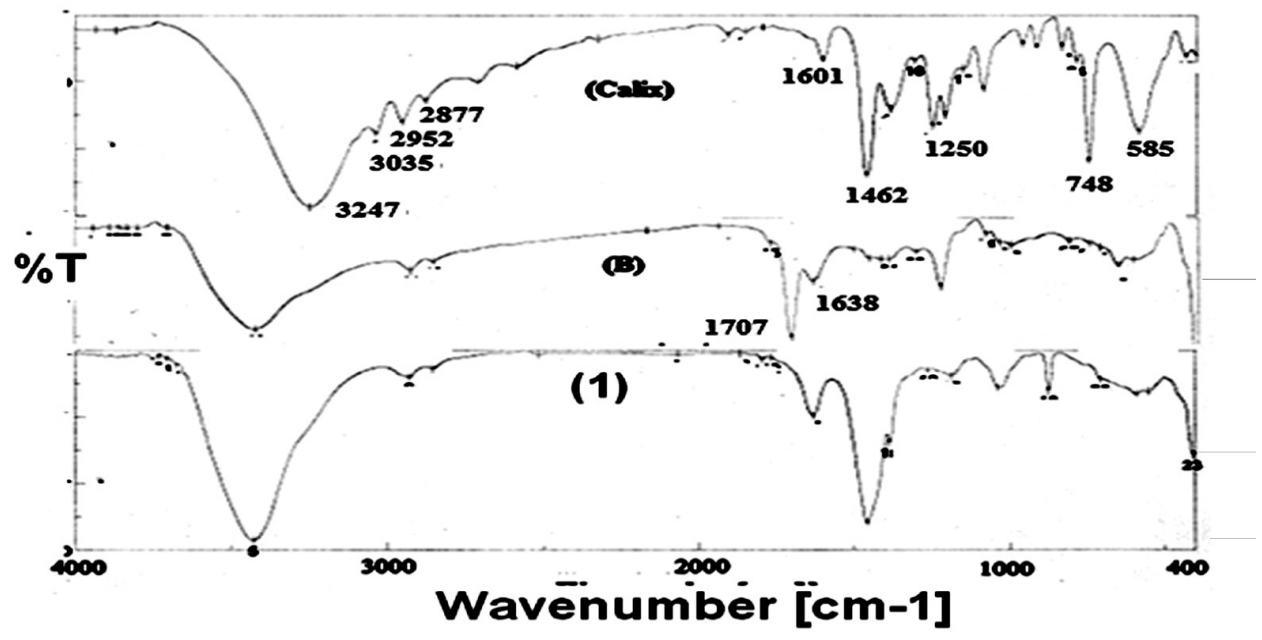

Fig 1. FTIR spectra of the prepared levansucrase immobilized formulations (1) MWCNTs/GA in comparison with calix [8] arene and (B) MWCNTs.
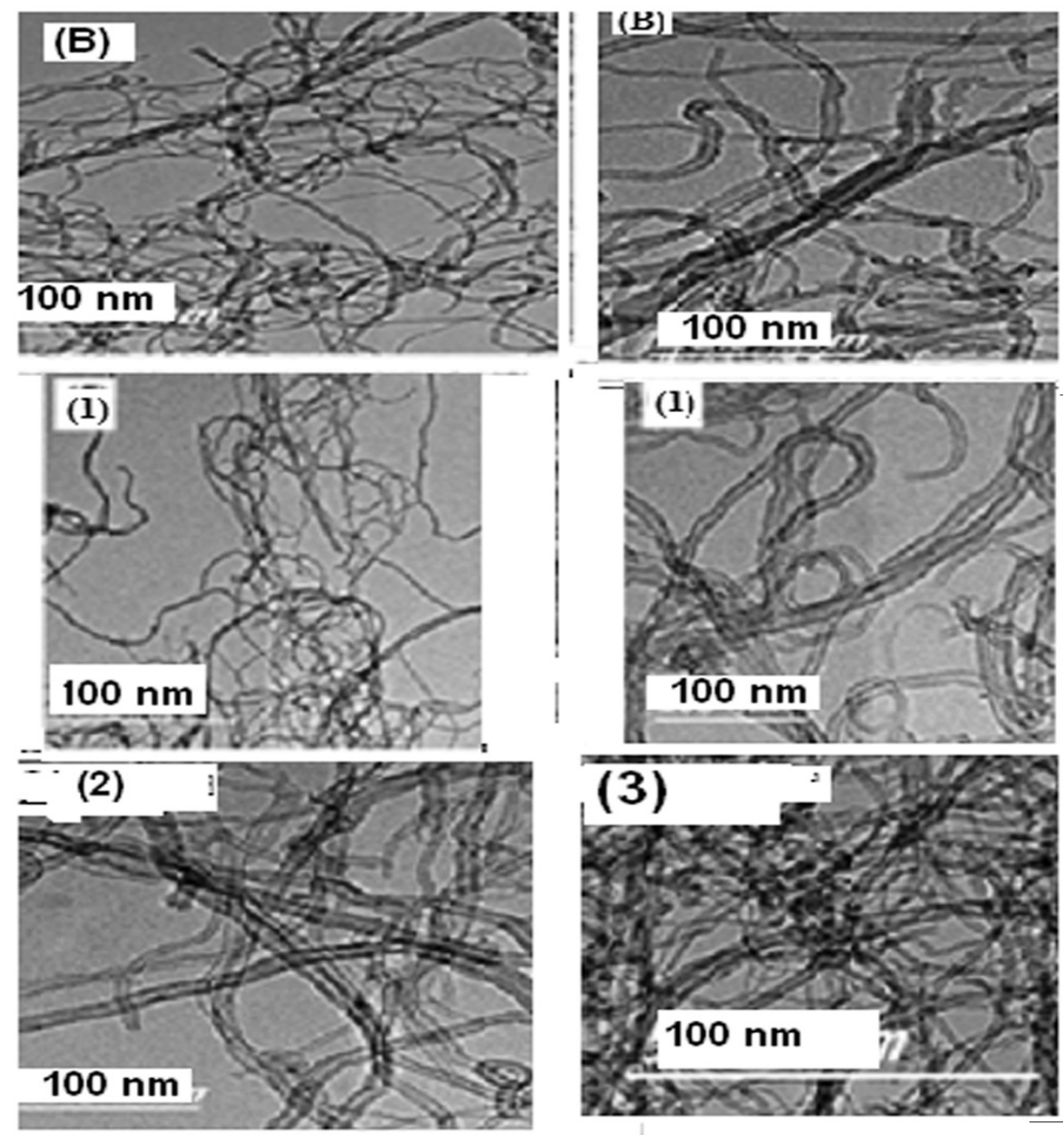

Fig 2. TEM images of the prepared levansucrase immobilized formulations (1) MWCNTs/Calix/GA, (2) MWCNTs/ Calix and (3) MWCNTs/Calix/EDC in comparison with (B) MWCNTs and the crosslinked ones. 


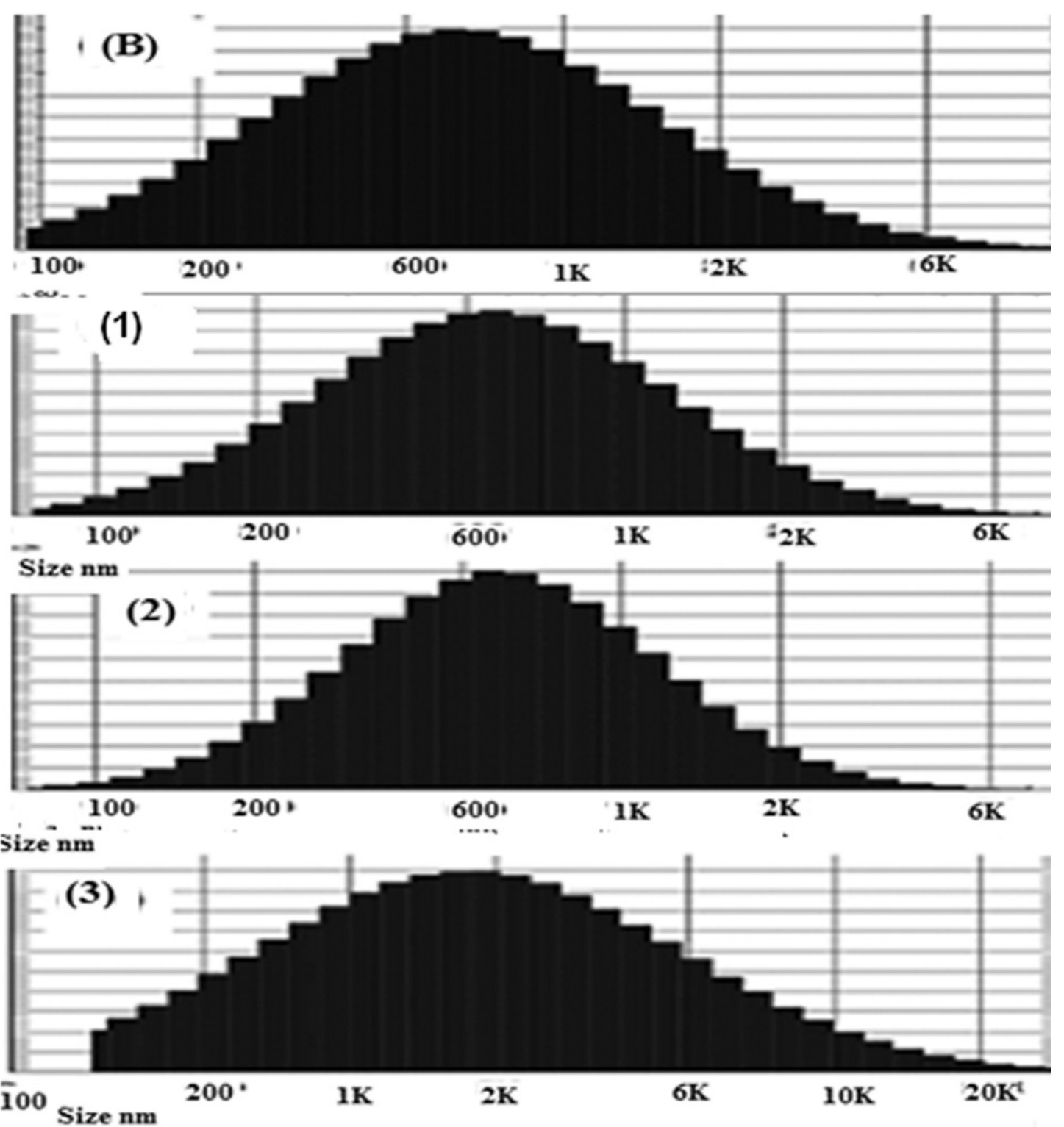

Fig 3. Particle size distribution analysis of the prepared levansucrase immobilized formulations 1) MWCNTs/ Calix/GA, (2) MWCNTs/Calix and (3) MWCNTs/Calix/EDC in comparison with (B) MWCNTs.

TABLE 3. Particle size distribution analysis of the prepared materials using DLS technique.

\begin{tabular}{ccc}
\hline Sample Code & Particle size (nm) & Variance (PDI) \\
\hline (B) & $419 \pm 302$ & 0.521 \\
(1) & $746 \pm 516$ & 0.479 \\
(2) & $784 \pm 485$ & 0.382 \\
(3) & $938 \pm 831$ & 0.782 \\
\hline
\end{tabular}



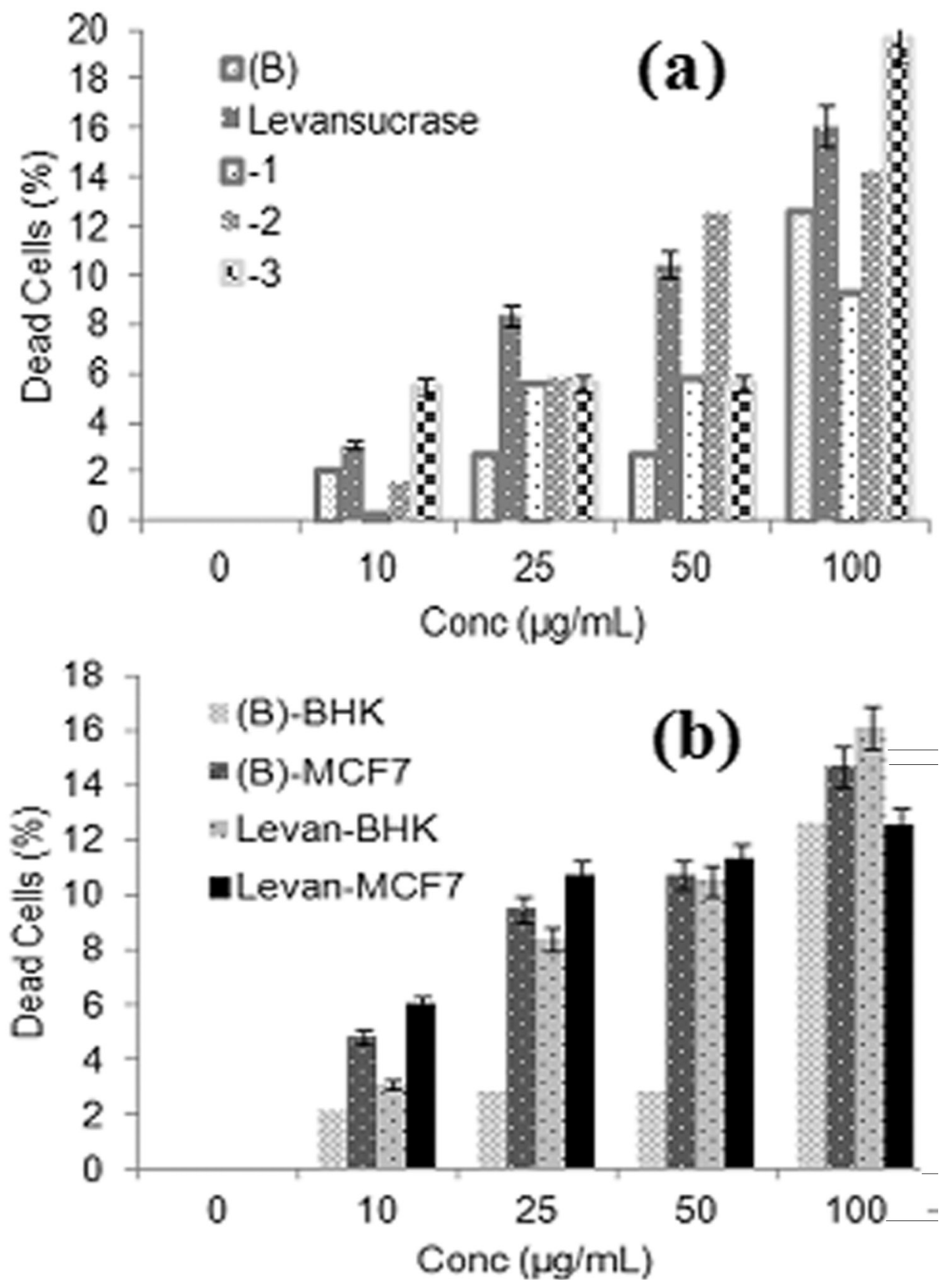

Fig 4. In vitro cytotoxic activity of the prepared levansucrase immobilized formulations [a] 1) MWCNTs/Calix/GA, (2) MWCNTs/Calix and (3) MWCNTs/Calix/EDC in comparison with (B) MWCNTs and free enzyme using BHK normal and [b] In vitro cytotoxic activity of MWCNTs in comparison with free enzyme (levan) using BHK and MCF7 cell lines using SRB assay. 

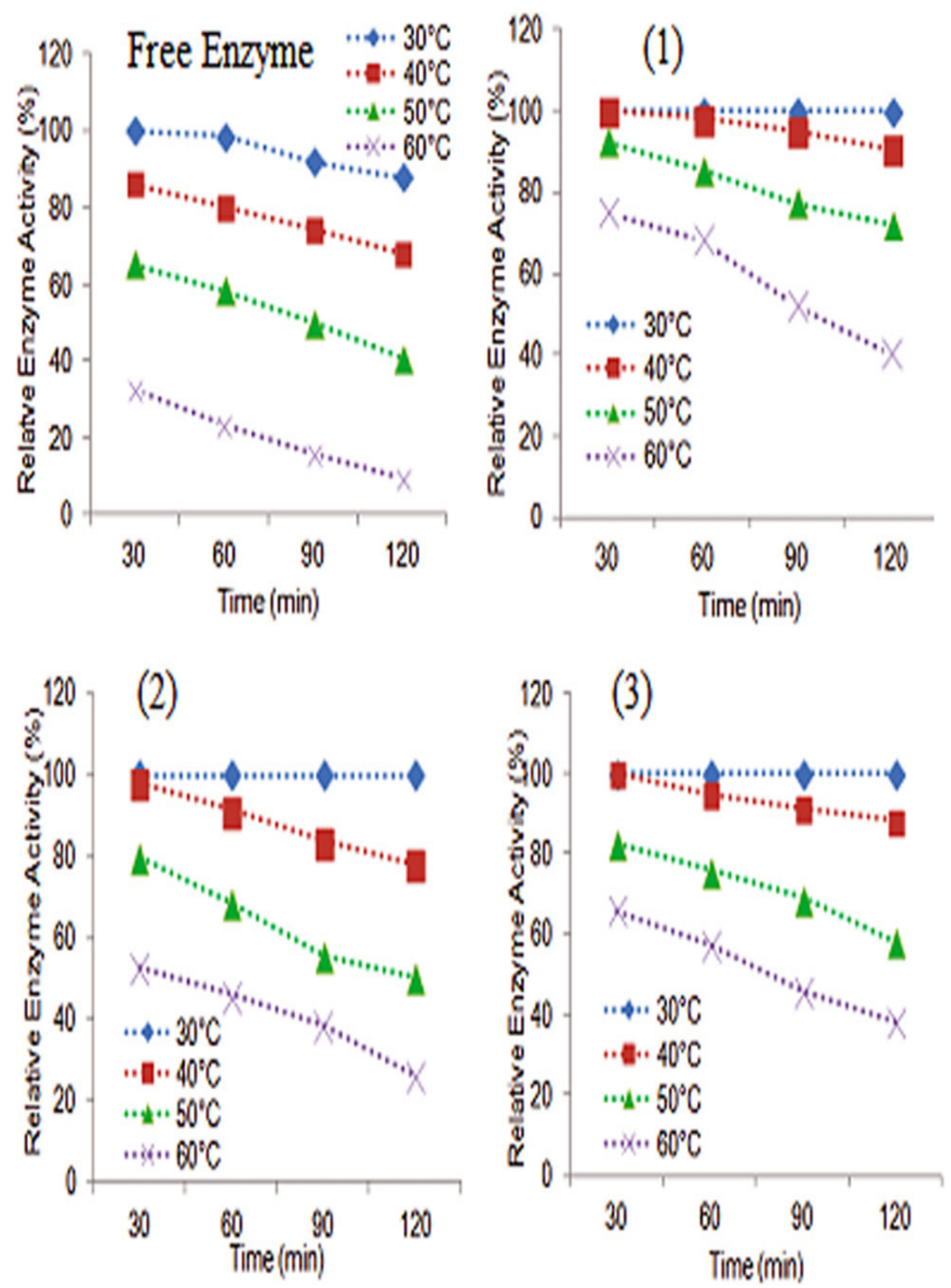

Fig. 5. Thermal stability profile of the prepared Levansucrase free and immobilized formulations (1) MWCNTs/ Calix/GA, (2) MWCNTs/Calix and (3) MWCNTs/Calix/EDC in comparison with free enzyme. 


\section{Conclusion}

This study is a new trial to overcome the problems of levansucrase immobilization through the prepared new formulations based on MWCNTs and calix[8]arene. Levansucrase enzyme was produced from pure honey using new isolate microbes coded $\mathrm{H}_{1}, \mathrm{H}_{2}, \mathrm{H}_{3}, \mathrm{H}_{4}$ and $\mathrm{H}_{5}$. The promising levansucrase producer strain was identified as Bacillus subtilis. Besides, three formulations with different enzyme concentrations were prepared and characterized. Levansucrase was successfully immobilized onto functionalized MWCNTs using simple covalent binding technique. Moreover, the cytotoxicity of the immobilized enzyme could be minimized up to $100 \mu \mathrm{g} / \mathrm{mL}$ concentration against BHK fibroblast normal cells in comparison with the free enzyme and MWCNTs. This finding becomes a common goal for many workers in the microbiological and medical fields.

\section{Acknowledgment}

The authors acknowledge National Research Centre for financial support of this research work related to the project number: 11090308 .

\section{References}

1. Hilder TA, Hill JM. Theoretical comparison of nanotube materials for drug delivery. Micro Nano Lett. 3, 18 (2008).

2. Hala A. Amin, Haroun AA. Comparative studies of free and immobilized aspergillus flavus onto functionalized multiwalled carbon nanotubes for soyasapogenol B production. Egyptian Pharma J. 16, 138 (2017).

3. Haroun AA, Amin HA, Abd El-Alim SH. Preparation, Characterization and in vitro biological activity of soyasapogenol B loaded onto functionalized multi-walled carbon nanotubes. Current Bioactive Compounds in press (2017). DOI:10.2174/1573407213666170407165917

4. Pavlidis I.V., Tsoufis T., Enotiadis A., Gournis D. Stamatis H. Functionalized multi-wall carbon nanotubes for lipase immobilization. Adv. Eng. Mater.12, 179 (2010).

5. Shah S., Solanki K., Gupta M.N. Enhancement of lipase activity in non-aqueous media upon immobilization on multi-walled carbon nanotubes. Chem Central J. 1, 30 (2007).

6. Zhang P, Henthorn DB. Synthesis of PEGylated single wall carbon nanotubes by a photoinitiated Egypt. J. Chem. 61, No. 4 (2018) graft from polymerization. AIChE $J \mathbf{5 6}, 1610$ (2010).

7. Feng W, Ji P. Enzymes immobilized on carbon nanotubes. Biotechnol Adv. 29, 889 (2011).

8. Wang L, Jiang R. Reversible his-tagged enzyme immobilization on functionalized carbon nanotubes as nanoscale biocatalyst. Methods $\mathrm{Mol}$ Biol. 743, 95 (2011).

9. Cang-Rong JT, Pastorin G. The influence of carbon nanotubes on enzyme activity and structure: investigation of different immobilization procedures through enzyme kinetics and circular dichroism studies. Nanotechnol 20, 255102 (2009).

10. Khaled E., Kamel M.S., Hassan H.N.A., Haroun A.A., Youssef AM., Aboul-Enein HY. Novel multiwalled carbon nanotubes/ $\beta$-cyclodextrin based carbon paste electrode for flow injection potentiometric determination of piroxicam. Talanta 97, 96 (2012).

11. Haroun AA., Taie H.A. Characterization and in vitro cytotoxicity study of functionalized carbon nanotubes using ß-cyclodextrin. Macromol. Symp. 337, 25 (2014).

12. Haroun AA., Elnahrawy A M., Abd-Alla H. I.. Sol-gel preparation and in vitro cytotoxic activity of nanohybrid structures based on multi-walled carbon nanotubes and silicate. Inorganic and Nano-Metal Chem 47, 1023 (2017).

13. Haroun A.A., Amin H. A., Abd El-Alim S. H.. Immobilization and in vitro evaluation of Soyasapogenol B onto Functionalized Multiwalled Carbon Nanotubes. IRBM 39, 35 (2018).

14. Hala A. Amin, Ahmed A. Haroun. Comparative studies of free and immobilized Aspergillus flavus onto functionalized multiwalled carbon nanotubes for soyasapogenol B production. Egyptian Pharmaceutical J. 16, 138-143 (2017).

15. Abdel Naby AM, Hashem. MA, Esawy MA Immobilisation of Bacillus subtilis œ-amylase. and characterization of its enzyme properties, Microbial Res. 153, 319 (1998).

16. Cordeiro A.L., Lenk T., Werner C., Immobilization of Bacillus licheniformis $\alpha$-amylase onto reactive polymer films. J. Biotechnol. 154, 216 (2011).

17. Karam EA, Wahab WAA, Saleh SAA, Hassan ME, Kansoh AL, Esawy MA. Production, immobilization and thermodynamic studies 
of free and immobilized Aspergillus awamori amylase. Int J. Biol Macromol 102, 694 (2017).

18. Velázquez-hernandes M. L., Baizabal-Aguirre V. M, Bravo-Patiño A., Cajero-juárez M., Chávezmoctezuma M.P., Valdez-Alarcón J.J. Microbial frusctosyltransferases and the role of fructans. J. Appl Microbiol 106, 1763 (2009).

19. Hill A, Karboune S., Cesar Mateo C. Immobilization and stabilization of levansucrase biocatalyst of high interest for the production of fructooligosaccharides and levan. J. Chem Technol Biotechnol. 91, 2440 (2015).

20. Euzenat O., Guibert A., Combes D. Production of fructo oligosaccharides by levansucrase from Bacillus subtilis C4. Proc Biochem 32, 237 (1997).

21. Esawy MA, Abdel-Fattah, AF, Mahmoud DAR. Immobilisation of Bacillus subtilis NRC33a levansucrase and some studies on its properties. Brazil J. chem Eng. 25, 237 (2008).

22. Baxevanis A.D.: The molecular biology database collection: an online compilation of relevant database resources. Nucleic Acid Research 28, 1 (2000).

23. Marshall MW, Popa-Nita S, Shapter JG. Measurement of functionalized carbon nanotubes carboxylic acid groups using a simple chemical process. Carbon 44, 1137 (2006).

24. Lowry oh, Rosebrough NJ., Farr AL., Randall RJ. Protein measurement with the Folin phenol reagent. J. Biol Chem. 193, 265 (1951).
25. Wang L., Wei L., Chen Y., Jiang R. Specific and reversible immobilization of NADH oxidation on functionalized carbon nanotubes. J. Biotechnol. 150, 57 (2010).

26. Yanase H, Iwata M, Nakahigashi R, Kita K, Kato $\mathrm{N}$, Tonomura K Purification, crystallization, and properties of extracellular levansucrase from Zymomonas mobilis. J Biosens Biotechnol Bioch 56, 1335 (1992).

27. Sehkan P., Storeng R., Scudiero D., Monks A., McMahon J., Vistica D., Warren J.T., Bokesch H., Kenney S., Boyd M.R. New colorimetric cytotoxicity assay for anticancer-drug screening. $J$ Natl Cancer Inst. 82, 1107 (1990).

28. Abdel-Fattah A.F.., Mahmoud D.A.R., Esawy M.A., Production of Levansucrase from Bacillus Subtilis NRC33a and Enzymic synthesis of levan and fructo-oligosaccharides. Current Microbiol 51, 402 (2005).

29. Shih L., Yu Y.T., Shieh C.J., Hsieh C.Y., Production and characterization of levan by Bacillus subtillis. J. Agric Food Chem. 53, 8211 (2005).

30. Veesar I..A.., Solangi I.B., Memon S., Immobilization of $\alpha$-amylase onto a calix[4]arene derivative: Evaluation of its enzymatic activity. Bioorganic Chem. 60, 58 (2015).

31. Hill A., Karboune S., Mateo C. Investigating and optimizing the immobilization of levansucrase for increased transfructosylation activity and thermal stability. Proc Biochem 61, 63 (2017).

(Received 18/4/2018; accepted 31/5/2018) 


\section{تحميل وتوصيف إنزيم ليفان سكراز علي أنابيب الكربون النانومتريه الوظيفيه متعددة

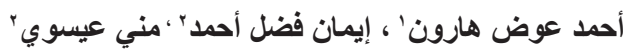

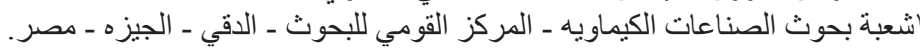

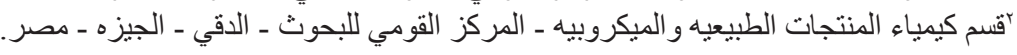

ماز ال إستخدام الانزيمات في بعض التطبيقات الصناعيه محدودا نتيجة لعدم ثباتها تحت ظروف التبات التشغيل و التكلفه

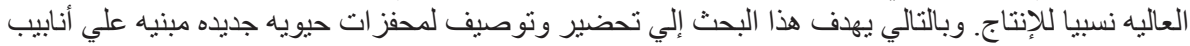

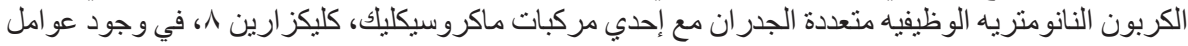

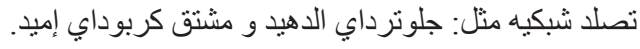

تم إختبار خمس عزلات ميكروبيه من العسل الطبيعي وكان أكثر هم إنتاجا لإنزيم ليفان سكراز ميكروب باسبلس سبتلس.

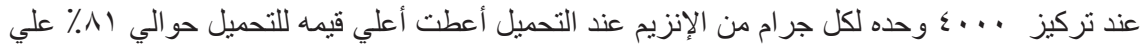

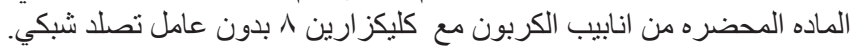

تم توصيف المو اد المحضره بإستخدام طيف الاشعه تحت الحمر اء، الميكرسكوب الإلكتروني النافذ بالإضافه إنهاته

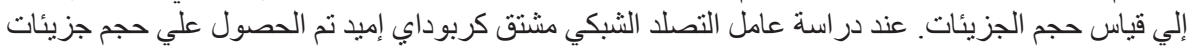

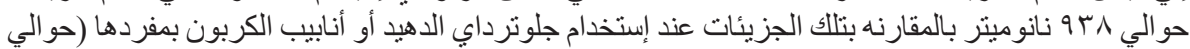

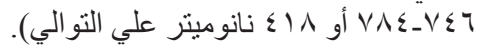

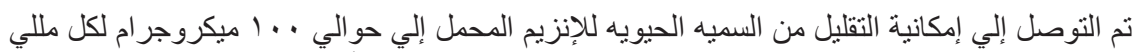

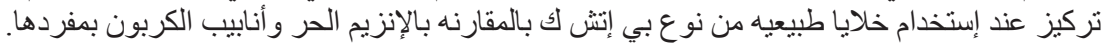

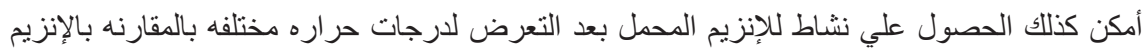

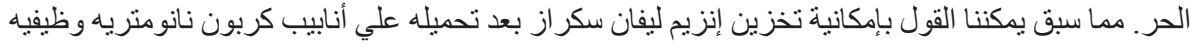

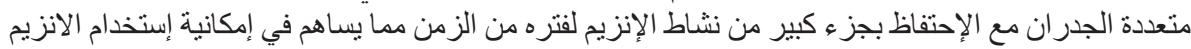

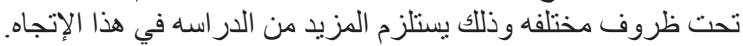

